\title{
Forskningsformidlingens veje og vildveje
}

\section{Anmeldelse af Leif Kajberg}

Jørgen Burchardt: Hvidbog om dansk forskningsformidling: Viden giver velstand. Odense: Syddansk Universitetsforlag, 2007. 56 s. ISBN 978-87-7674233-1. Jørgen Burchardt: Fra universitet til samfund: Forskningsformidlingens infrastruktur. Bilag 1 til Hvidbog om dansk forskningsformidling. Odense: Syddansk Universitetsforlag, 2007. 186 s. ISBN 978-87-7674-234-8 Jørgen Burchardt: Selskaber og tidsskrifter: Forskningsformidlingens infrastruktur. Bilag 2 til Hvidbog om dansk forskningsformidling. Odense: Syddansk Universitetsforlag, 2007. 484 s. 978-87-7674-235-5

Den 18. juni 2007 udkom seniorforsker Jørgen Burchardts udredning om dansk forskningsformidling. Det samlede udredningsmateriale består af en kortfattet fremstilling "Hvidbog om dansk forskningsformidling" og to bilagsbind "Fra universitet til samfund: Forskningsformidlingens infrastruktur" og "Selskaber og tidsskrifter: Forskningsformidlingens infrastruktur." Jørgen Burchardts udredning kom ikke til at mangle forskræp; Ugebrevet Mandagmorgen kørte således en historie i 18. juni-udgaven med overskriften "Forskning skal ud til brugerne," i hvilken der lamenteres over den danske forskningsformidlings aktuelle dårligdomme: Formidlingsindsatsen savner fokus, systematik og retning. Formidlingsaktiviteterne er underprioriterede, og forskerne selv er for usynlige i offentligheden. Der er også hug til forskningsbibliotekerne for undladelsessynder på

Leif Kajberg er forskningskonsulent ved Danmarks Biblioteksskole.lk@db.dk registrerings- og indekseringsfronten. Mandagmorgens historie, som også bygger på et interview med udrederen selv, kommer således rundt om mange hjørner, men alligevel sidder man som læser tilbage med fornemmelsen af, at der mangler noget. Ugebrevet synes mest optaget af forskningsresultaternes omsættelighed udadtil og målretningen mod "slutbrugerne" i samfund og erhvervsliv. Med andre ord, hvis bare der kommer styr på formidlingen og dens strukturer, så er vejen banet for grydeklar forskningsbaseret viden og øget værditilvækst i virksomhederne. Så nemt er det naturligvis ikke. Opgradering af forskningsformidlingen og forbedret adgang til forskningsprodukterne er én ting; en anden ting er den faktiske udnyttelse af forskningsresultaterne og de potentielle brugeres forhold til den forskningsproducerede viden. Det skal jeg komme tilbage til. Det er imidlertid væsentligt at fremhæve, at udredningen byder på analyser og iagttagelser, som ikke rigtig kommer frem i Mandagmorgens historie. Eksempelvis redegørelsen for tidsskrifter og andre formidlingskanaler som "økologisk system" og ikke mindst tidsskrifternes overlevelseskamp. Plus de informationspolitiske overvejelser over elektronisk publicering og offentliggørelsesformer. Altså i høj grad meget af det, som har med forskningsverdenens egne interne processer, normer og eksistensvilkår at gøre.

Selve hvidbogen indeholder de sammenfattende iagttagelser og hovedbudskaberne, medens bilagsbindene viderebringer resultaterne af faktaindsamling, optællinger og analyser. En omfattende stifindervirksomhed i den danske forskningsverden viste sig 
nødvendig, fordi information om formidlingssystemets komponenter, aktører og virkemåde ikke var umiddelbart tilgængelig. Følgelig måtte et vidtstrakt og uigennemsigtigt forskningslandskab afsøges med tættekam og lup. De mange tusinde forskeres aktive indsats i spredningen af forskningsresultater er desværre usynlig og underkendt udadtil. Derfor må forskningsformidlingens infrastruktur forbedres og moderniseres samtidig med, at man står vagt om princippet om fri og åben adgang til videnskabelig information i dens forskellige former. Hvidbogen forholder sig også til udlandskonkurrencen, og der er forslag til, hvordan danske forskere kan blive mere synlige og stå sig bedre i konkurrencen med ikke mindst de udenlandske forskere, der har engelsk som modersmål, og som bekvemt kan betjene sig af hele spektret af engelsksprogede formidlingsmedier. Men ved en overkommelig indsats kan danske forskeres resultater både gøres mere tilgængelige og spredes mere effektivt. Midlet hertil er i høj grad de web-baserede formidlingsformer og de mange hundrede domæne-specifikke selskaber og foreninger.

En følgegruppe har fungeret parallelt med udredningsarbejdet, men synspunkterne og forslagene er pennefører og udreder Jørgen Burchardts personlige, og de afspejler dermed ikke nødvendigvis følgegruppens opfattelse af tingene. Følgegruppens sammensætning kan virke lidt ensidig både med hensyn til repræsenterede videnskabelige domæner og institutionstilknytningen.

Bilagsbindet "Fra universitet til samfund" analyserer videnskabsformidlingen $\mathrm{i}$ et generelt perspektiv med afstikkere til videnledelse, knowledge management. Forfatteren præsenterer en kommunikationsmodel for "forskningens fødekæde," og desuden analyseres den aktuelle danske forskningsformidling og de danske bogforlag og deres aktiviteter. Alle danske universitetsforskeres produktion i 2004 er, oplyses det, blevet identificeret og analyseret. Dvs. oplysningerne om den skriftlige produktion, som indgår i analysen, stammer fra "alle landets 12 universiteter." Derved fås et samlet materiale, der omfatter 25.000 forskellige bidrag, og som er blevet analyseret ud fra forskellige vinkler. Det fremprovokerer uundgåeligt den syrlige anmelderbemærkning, at oplysningen om, at alle danske universitetsforskeres produktion er medtaget som analysegrundlag, dermed ikke holder vand. Der er nemlig flere universiteter i Danmark end de 12 under Videnskabsministeriets ressort. Der findes jo også universitære institutioner under Kulturministeriet, f.eks. konservatorier, arkitektskoler og Danmarks Biblioteksskole. OK, deres andel af den samlede danske forskningsproduktion i universitetsregi er meget begrænset, men deres publikationsvolumen burde have været medtaget i denne sammenhæng. Det andet bilagsbind ("Selskaber og tidsskrifter") er anlagt som en vejviser med oplysninger om de 623 videnskabsformidlende tidsskrifter og de 500 foreninger, der udgør en væsentlig del af den videnskabelige netværksdannelse i Danmark. En enkelt forglemmelse, som nærværende anmelder faldt over: Dansk Bibliotekshistorisk Selskab, som ikke er nævnt.

Beskrivelsen af vidensformidlingens fødekæde, forskningsresultaternes vej til målgrupper og aftagere, er meget nyttig og illustrativ. Der gives detaljeret besked om formidlingsmedierne og deres særpræg og om formidlingsprocessen. Dog virker nogle af forklaringerne lidt omstændelige, selvindlysende og selvhøjtidelige. Samme betragtning gælder beskrivelsen af forskersamfundet, dets mødeformer og formidlingspraksis, som forekommer lidt vel "pædagogisk" og udpindende; men måske er det nødvendigt, hvis man vil have beslutningstagere og målgrupper uden for forskernes egne fagmiljøer og netværker i tale. Analyseresultaterne dokumenterer, at danske forskere er meget internationalt orienterede.

Også kvalitetssikringen af forskningsresultaterne får nogle ord med på vejen. Man trækker i denne forbindelse lidt på smilebåndet, når man støder på en formulering af typen: "Bemærk at en artikelforfatter sjældent leverer et færdigt produkt, men at det at skrive til et tidsskrift mere er en proces, som lutrer den akademiske renhed i processen mod det uopnåelige mål: den perfekte artikel." Altså, sikke en højstemt og andægtig formulering. Man ser for sig kigget ind i forskerens værksted med ansigtet lagt i behørigt benovede folder... Man fornemmer klart forfatterens lunkenhed over for peer reviewing-princippet. Dette vurderings- og filtreringssystem har sine begrænsninger, og specielt inden for humaniora og samfundsvidenskab kommer det efter forfatterens opfattelse til kort.

En detalje: Man hæfter sig ved, at der på s. 30 (i hvidbogen), i oversigten over fordelingen af udgivelsestyper på fagområder, optræder en fagbetegnelse, "Bog, bibliotek," men det er ikke lige til at gennem- 
skue, om, og i hvilket omfang, biblioteks- og informationsvidenskab er repræsenteret af denne kategori. Tilsyneladende indgår Danmarks Biblioteksskoles forskningsproduktion ikke i optællingerne.

Under overskriften "Fri og gratis forskning til samfundet" plæderes der i hvidbogen for, at artikler skal spredes via nettet og være tilgængelige efter open access-princippet. Der gøres meget ud af at understrege vigtigheden af at synliggøre tidsskrifterne og deres indhold på internettet på en systematisk, overskuelig og brugervenlig facon. Forfatteren mener, at der skal gøres en økonomisk og organisatorisk indsats for at sikre, at forskningsresultaterne on-line-tilgængeliggøres uden afgift for brugerne. Også de videnskabelige selskaber bør oppe sig med hensyn til at anvende nettet til synliggørelse og formidling af elektroniske forsknings-informationsressourcer.

En af rapportens mere håndfaste udmeldinger er, at forskningsformidlingsindsatsen, forankret som den er i forskernes frivillige arbejde, er i defensiven og $\mathrm{i}$ politisk henseende står svagt. Fraværet af organisationer, som er fortalere for videnskabelig formidling - der findes instanser af denne type i f.eks. Finland og Canada - er et føleligt problem. Det er nok rigtigt, der er jo et tomrum i Ministeriet for Videnskab og Teknologi, og et organ som DANDOK, det tidligere Statens Udvalg vedrørende Videnskabelig Information og Dokumentation (nævnt i bilag I på s. 39), er jo for længst ophørt med sin virksomhed. Det foreslås derfor, at der etableres en organisation eller måske blot et samråd, der kan varetage forskningsformidlingens interesser i Danmark.

Bilag 1 "Fra universitet til samfund" rummer en række empirisk baserede iagttagelser af videnskabelige domæners publiceringspraksis. Der findes desuden indgående analyser af tidsskrifternes økonomi, bl.a. prisudviklingen (s. 44-51, Bilag I). De danske forskningsformidlende tidsskrifter er en truet race, og en af de alvorlige knaster er distributionsomkostningerne. Tidsskrifternes trivsel og overlevelseskamp blev væsentligt forværret med den borgerlige regerings afskaffelse af portostøtten i 2004. I det aktuelle trusselsbillede indgår desuden den høje moms. På s. 35 i hvidbogen præsenteres en tabellarisk oversigt over forskellige økonomiske modeller for publicering af artikler med angivelse af fordele og ulemper ved udgivelsesformen. Central er i denne forbindelse gennemgangen i Bilag I af de interessemodsætninger (tidsskrifter, biblioteker, universiteter, forlagsverden mv.), som karakteriserer diskussionen af tilgængelighedsformerne. Fra en sprogpolitisk vinkel argumenteres der for en dobbeltstrategi, der dels sikrer, at danske forskningsresultater er tilgængelige for befolkningen, og dels retter sig mod formidlingen af de primære forskningsresultater på et fremmedsprog.

Jørgen Burchardt opholder sig meget ved det fagbibliografiske systems dokumenterede lakuner og viderværdigheder. Vi bliver mindet om, at en forudsætning for nyttiggørelsen af forskningsresultater er, at de potentielle brugere er i stand til at skaffe sig kundskab om de publicerede resultaters eksistens. Uden dette kendskab forbliver den eksisterende viden lukket land for brugerne. Manglerne i den fagbibliografiske dækning er ikke nogen ny problemstilling, den er bl.a. velkendt på Biblioteksskolen, i undervisningen og i den faglige debat, og Erland Munch-Petersen, i en årrække fagleder ved Danmarks Biblioteksskole og senere professor ved Gøteborgs Universitet, var således meget optaget af fagbibliografiens degenerering og nedprioritering. Ofte er det mangel på ressourcer, som er årsag til miseren på dette område. Der er også kritik af Den Danske Forskningsdatabase, der karakteriseres som "en vingeskudt svane", som kun mangelfuldt registrerer den danske forsknings frembringelser. En mangelsituation, der også gælder de elektroniske forskningsudgivelser. Det påvises tillige, at danske forskeres resultater, sådan som de præsenteres i bøger, artikler og andre publiceringsformater, registreres lemfældigt og ujævnt i internationale bibliografier og databaser. Men synderegistret er længere, det omfatter f.eks. også de hjemlige ph.d.-afhandlinger, som kan være meget svære at opspore og få fingre i, og hvor det landsdækkende systematiske overblik mangler. En bedre databaseregistrering er derfor et must, og dækningen må derfor udvides til at omfatte publikationsformater som f.eks. forsknings- og arbejdspapirer, personlige profiler, omtale af nye bøger og tidsskrifter i redigeret form, der er tilgængelige for en bredere offentlighed, resuméer fra konferencer og seminarer. Det skorter ikke på idéer til videreudvikling af en sådan base, med overbygninger, metadata, fagportaler, formidlingsmekanismer af mere journalistisk tilsnit m.v., men spørgsmålet er vel også, hvordan man kan få det hele til at gå op i en højere enhed, om man kan få interessenter og inputleverandører til at medvirke med den nødvendige disciplin og regularitet. Og hvordan med synliggørelsen af basen og det forventede bru- 
gertræk på databasen midt i en Google-tid? Institutional Repositories, elektroniske registre og arkiver med e-publicerede afhandlinger f.eks. og drevet af de akademiske institutioner selv, altså institutionsdatabaser, synes derimod - i forfatterens optik - at være af det onde. De betragtes faktisk som parasitter, der dræber deres vært. Vi har dræbersnegle og dræbergopler, nu skal man altså også til at operere med dræberarkiver. - Det vil bl.a., fremføres det, svække forlagenes interesse $\mathrm{i}$ at papirpublicere bearbejdede afhandlinger og dermed give færre incitamenter til udgivelse og distribution i bogform.

Hvidbogen præsenterer en omfattende vifte af anbefalinger (på s. 54-56), lige fra forslag til et 4-årigt udviklingsprojekt, der skal styrke og reformere forskningsformidlingen i Danmark, til markering af behovet for ressourcer til kompetenceløft og faglig dygtiggørelse inden for fagvidenskabelige selskaber og foreninger.

Samlet set er stoffet, som det fremlægges i specielt bilagsbindet "Fra universitet til samfund," utrolig relevant, også for aktiviteterne på Danmarks Biblioteksskole. Empirisk underbyggede oversigter over problemstillinger inden for forskningens vidensproduktion og -formidling af dette omfang er der ikke mange af på dansk, og udredningsmaterialet byder i rigt mål på udfordringer, idéer og problemstillinger, som også bør interessere lærere på Danmarks Biblioteksskole, der underviser og forsker i informationsspredning, vidensproduktion, vidensstrukturer, typologi, brugerklienteller mv. inden for domæner. Hvidbog og bilag kunne desuden fortjene at indgå som baggrundsmateriale i læse- og pensumlister på bacheloruddannelsen på Danmarks Biblioteksskole. Pudsigt nok synes forfatteren at have overset Danmarks Biblioteksskole og skolens forgrenede fagekspertise i sit kortlægningsarbejde. En del VIP'er ved Biblioteksskolen har i årenes løb beskæftiget sig med problemstillinger inden for forskningsproduktion og -formidling. Axel Andersen, tidligere fagleder ved skolen, udgav således allerede i 1978 en populært anlagt introduktion til forskningsverdenen og forskningsformidlingssystemets produktionsforhold og sociologiske mekanismer "Forsker og samfund" (Andersen, 1978). Det var i øvrigt Axel Andersen, der plejede at sige, at forskning er 10\% inspiration og $90 \%$ transpiration, og denne mundrette karakteristik illustreres jo ganske glimrende af de tusindvis af frivillige forskeres engagement i de mangeartede for- midlings-, redigerings, evaluerings- og kvalitetskontrolrutiner, sådan som Jørgen Burchardt så præcist har demonstreret det i sit værk om forskningsformidlingen i Danmark. En af skolens nuværende lærere, Vibeke Horsten, færdiggjorde i 1993 et kompendium med titlen "Dansk Forskning: Organisation og institutioner" (Horsten, 1993).

Ingen er i tvivl om, at store dele af samfundet i dag efterspørger forskningsresultater. Det fremhæves til ulidelighed i medierne. Virksomhederne har brug for forskning til styrkelse af deres konkurrencekraft i globaliseringens tidsalder, og for den offentlige sektors institutioner er det forskningsmæssige input et must, hvis man skal sikre slagkraft, omstillingsevne, innovation, dynamik mv. Men hvad er det så for et forskningsindhold, der rent faktisk er brug for? Er råvaren i form af artiklen, antologibidraget eller ph.d.-afhandlingen standardsvaret $i$ alle sammenhænge? Og hvordan med bearbejdelsen, raffineringen, forædlingen og nyttiggørelsen af forskningsprodukterne? Det er gammelkendte problemstillinger inden for f.eks. biblioteksverdenen, de teknologiske servicecentre og dele af konsulentbranchen. Spørgsmålet er i høj grad - for nu at tage tråden op fra indledningen om, Mandagmorgens historie om forskningsformidling og vidensdeling - hvad det er for en type forskningsinformation, brugerne efterspørger. Og hvilke adgangsveje til forskningen, de ønsker at betjene sig af. Brugerne har det måske bedst med personkontakter og netværker, har måske ikke tid til at læse artikler, og griber allerhelst til knoglen og e-mailen. Alt det er velkendt stof. VidenDanmarks nyhedsbrev (2007) har løbende talrige synspunkter og artikel- og bogomtaler mv., der meget præcist illustrerer vidensformidlingens, vidensudnyttelsens, innovationens og innovationsbarrierernes kompleksitet. En kættersk tanke sniger sig ind: Tilgængelighed, overblik, pålidelig registrering og perfekte søgesystemer på forskningsområdet er måske ikke nok. Måske er det brugerne, der har et problem, mere end f.eks. bibliotekerne? Måske skal man ikke have overdrevent store forventninger til, hvad forskernes vidensreservoirer, faglige netværker og forskelligartede publiceringskanaler umiddelbart kan stille til rådighed for f.eks. erhvervslivsbrugere. Der kan være en tendens til over én bank at glorificere forskningsresultaterne i deres formodede pure og jomfruelige form. Adgangen til den forskningsproducerede viden er selvfølgelig essentiel, og det samme gælder serviceringen af dem, der efterspørger forsknings- 
resultater og forskningsinformation (igangværende projekter). Men bolden har det med at hoppe over på forskningsbrugernes banehalvdel. Tager man de informationshistoriske briller på, er der grund til hæfte sig ved, at det aldrig for alvor lykkedes f.eks. information broker-fænomenet at slå rod i Danmark. Information overload-faktoren er også relevant i denne sammenhæng. For nogle måneder siden kom det f.eks. frem, at man inden for bygge- og anlægssektoren i dens forgreninger - producenter af materialer, arkitektvirksomheder, konstruktører, entreprenører, rådgivning, logistik, håndværkere etc. - ikke er gode nok til at udnytte tilgængelig viden; tid og overskud mangler; man har simpelt hen for meget at rive i i det daglige. Mentalitetsbarrierer og træghedsfaktorer er indlejret i de processer, der har med systematisk videnstilegnelse og -udnyttelse at gøre. Med andre ord, kompleksiteten og differentieringen på brugerområdet er en afgørende faktor. Som det er tilfældet med universiteterne, har mange virksomheder i en årrække anset det for meget vigtigere at sprede information om sig selv udadtil, om egen fortræffelighed, end at satse på egentlige informationsinfrastrukturer med f.eks. biblioteksfunktion, informationsarkitektur og fagspecialister inden for vidensstyring mv. Derfor er der blevet spenderet store summer på ansættelse af journalister og informationschefer.

Det er et meget værdifuldt materiale, Jørgen Burchardt har samlet i specielt bilag I "Fra universitet til samfund." Den polemiske snert er tydelig flere steder, forfatteren skal af med mange personlige budskaber, og de præsenteres med et "journalistisk" drive. De mundrette overskrifter giver et indtryk af de mange kæpheste, der rides undervejs. Problema- tikken omkring Open Access-modeller og bibliotekernes påståede skurkerolle i denne forbindelse optager forfatteren meget. Der sættes også en tyk streg under hovedbudskabet om, at forskningsformidling i Danmark i stor udstrækning udføres af frivillige, og at værditilvæksten gennem redaktionsprocesser derved skabes uden udgift for det offentlige. Der tændes adskillige advarselslamper, og konturerne af markante fjendebilleder i forskningsformidlingens danske univers træder klart frem. Citationsanalyser er afgjort ikke forfatterens kop te. Men kritikpunkterne følges op af konstruktive forslag til, hvordan udviklingen kan vendes. Om der så kan skaffes politisk lydhørhed for den organisatoriske styrkelse af hele området med etablering af en styrelse for forskningsformidling og udviklingsprojekter, som der lægges op til, er en anden sag. Udredningsarbejdet er gennemført med tilskud fra Danmarks Elektroniske Forskningsbibliotek (DEFF).

Opfølgning på hvidbogen kan læses på: www.videnssamfundet.dk

\section{Litteratur}

Andersen, A (1978). Forsker og samfund: Tolv essays om den videnskabelige informationsformidling. København: Akademisk Forlag.

Horsten, V (1993). Dansk forskning: organisation og institutioner. En introduktion for bibliotekarer. København: Danmarks Biblioteksskole.

VidenDanmark, nyhedsbrev. Lokaliseret 20.8.2007 på WWW: http://www.videndanmark.dk/ 